\title{
First Batch of CoE B.Ed Student Teachers' Performance Level in General Biology Organised By UCC.
}

\author{
Ankomah R.*, Asamoah E., Owiredu J. K. \\ Department of Science Education, Abetifi Presbyterian College of Education, Box 19, Abetifi-Kwahu, Ghana \\ Email: amprofi2004@gmail.com
}

\begin{abstract}
The study investigated how the new four year Bachelor of Education degree students performed in their first ever quizzes organised by the University of Cape Coast (UCC). The student teachers were quizzed on some concepts in General Biology (EBS 103), a general course for all the forty-six (46) Colleges of Education in Ghana except students offering General Science as elective subject in the Colleges. The study involved the whole level hundred (L100) students of Abetifi Presbyterian College of Education who were selected through purposive and convenience sampling technique, totalling 435 students (195 female and 240 male). The test items used for the quizzes (Quiz 1 and 2) were constructed by Senior Lecturers of UCC with it reliability of 0.7 and its content and construct validity determined. Data was collected from the scores in both quizzes and were analysed using both descriptive and inferential statistics. An independent sample $\mathrm{t}$-test conducted showed that there was a significant difference between the performance of the male student teachers and the female student teachers in both quizzes $(p=0.000, p>0.05)$. The findings further revealed that there was a higher mean score in the quiz one compared to quiz 2 ; however, the mean difference was statistically insignificant $(\mathrm{P}=0.623, \mathrm{p}>0.05)$.

Keywords: general biology, first four year degree programme, colleges of education
\end{abstract}

\section{Introduction}

Education is intended to make one well balanced with requisite knowledge, skills, values, aptitude and attitude to become functional and productive citizens for the total development and the democratic advancement of one's nation and other related matters. Over the past forty years, teacher education in Ghana has undergone a number of modifications. These modifications are a result of policy changes which are aimed at achieving the aforementioned attributes of education by the parliament of the Republic of Ghana. According to ${ }^{[2]}$, the changes have resulted in the production of different cohort of teachers with different certificates.

One of the educational sub-sectors that has seen most reforms due to it pivotal role it plays in facilitating quality education in general, is teacher education. Teacher education is to train professionally competent teachers for a rapidly changing world, by equipping them with critical thinking abilities, pedagogic skills and respect for core values of honesty, integrity, loyalty and compassion.

The Education ACT, Act 778 which was legislated in 2008 stated in Section $1^{[4]}$ that tertiary education shall consist of education provided in a university, polytechnic or college of education established by an Act of Parliament and accredited by the National Accreditation Board (NAB). According to ${ }^{[7]}$, Teacher Training Colleges were pre-tertiary institutions under the supervision of the Ghana Education Service-GES. The report further stated that, Esi Sutherland Addy report, 1987; White paper on reform to the tertiary education system, 1991; Akyeampong report, 1998; Anamuah-Mensah report, 2002 all recommended the upgrading of post-secondary training institutions including teacher training colleges to tertiary status.

Currently, in Ghana, all the forty six (46) Colleges of Education is considered as infant tertiary institution that will gradually become autonomous as tertiary institutions. Colleges of education are at the mentoring stage to affiliated tertiary institution together with ministries and other boards and council such as National Teaching Council (NTC), to collaborate and ensure that Colleges of Education are on their feet.

Again, the University of Cape Coast (UCC) is the affiliated institution for all the Colleges of Education in Ghana and it is charged to organise the first supervised test in General Biology for all student teachers offering Bachelor of Education in Primary Education in the Colleges of Education, a new four year programme for first year students for 2018/19 academic

Copyright (C2020 Ankomah R., et al.

DOI: https://doi.org/10.37256/ser.112020135.21-26

This is an open-access article distributed under a CC BY license

(Creative Commons Attribution 4.0 International License)

https://creativecommons.org/licenses/by/4.0/ 
year. In Abetifi College of Education, there are four hundred and thirty five students who have been group into five groups. Two of these groups (Group A and B) offer Primary Education programme and the other three groups-C, D and E offer Junior High School Programme with specialisation in Ghanaian Language and Religious and Moral Education (RME), Mathematics and Information Communication Technology (ICT), and Social Studies and ICT respectively. All these students were made to register for General Biology so as to understand our environment and appreciate how the living and the non-living interact among themselves to bring about a stable environment.

Again, this new four year programme comes not without some challenges. The challenges with regard to teaching, learning and assessment of the New Bachelor of Education programme in attaining a full autonomy as a tertiary institution has been in question in recent times, following the destiny' strike embarked upon by Colleges of Education teachers Association of Ghana (CETAG), demanding their status as other analogous tertiary institution in November, 2018, just when the programme was about to take off ${ }^{[4]}$. Hake explained that effective teaching and learning is correlated to effective gain (performance) ${ }^{[5]}$. As such, this study aims to report vividly whether the challenges with regard to teaching, learning and assessment of the New Bachelor of Education programme in attaining a full autonomy as a tertiary institution and on the readiness of the new four year Bachelor of Education Degree programme is on course. This study seeks to give a detailed study of student teachers performance (output) in the new four year Bachelor of education, a degree programme currently introduced into the Colleges of Education system in Ghana.

\subsection{Statement of the problem}

Bawa M. ${ }^{[3]}$ reported that the performance of Ghana's Junior High School pupils who were mostly taught by teachers from Colleges of Education in Ghana at first and second cycle levels of education in Ghana performed abysmally in the Trends in International Mathematics and Science Study (TIMSS) assessment in 2003 and $2007^{[1]}$. The programme of the new four year Bachelor of Education in Colleges of Education comes into force to address the issues of poor performance in Basic schools in Ghana ${ }^{[4]}$.

\section{Objectives of the study}

The Study sought to determine:

1) the performance level of student teachers in General Biology Quiz one and Quiz two.

2) whether there is a significant difference between the performance level of student teacher in Quiz one and Quiz two in General Biology.

\subsection{Research question}

What is the performance level of student teachers in both General Biology Quiz one and quiz two?

\subsection{Null hypothesis}

The null hypothesis formulated for the study is:

$\mathrm{H}_{\mathrm{o1}}$ : There is no significant difference between the mean scores in quiz one and quiz two.

$\mathrm{H}_{\mathbf{A} 1}$ : There is significant differences between the mean scores in quiz one and quiz two.

\subsection{Purpose of the study}

The purpose of the study was to find out the performance level of the first batch of four year B. Ed students in General Biology.

\subsection{Significance of the study}

Research has shown that, we can only develop as a country when we invest in research. This study will first of all be significant to course lecturers by influencing our method of teaching.

Secondly, it might inform stakeholders on decision making in relation to the new four year Bachelor of Education degree in Colleges of Education. Finally, it would inform sponsors about the readiness of the student teachers in relation to the B. Ed programme.

\subsection{Delimitation of the study}

The study was delimited to First year four year degree student teachers in Abetifi Presbyterian College of education, Abetifi -Kwahu. It was also delimited to the first and second General Biology quizzes organised by UCC in all the 46 Colleges of Education in Ghana. 


\section{Methodology}

\subsection{Research design}

Case study

\subsection{Population}

The population is all First year four years' degree student teachers in all the College of Education in Ghana offering Bachelor of Education Degree with the exceptions of Colleges offering General Science as elective.

\subsection{Sample and sampling techniques}

The sample is all first year (level 100) student teachers of Abetifi Presbyterian College of Education. The students have been grouped into five based on their area of specialisation. Group A and B offer Primary Education with specialisation in Religious and Moral Education, Information Communication Technology, English Language and Mathematics. Group A and B have total enrolment of eighty-six (86) and eighty-seven (87) students respectively. Group C, D and E respectively offer JHS Education with specialisation in Mathematics, Social Studies and English Language as electives. These groups again offer Religious and Moral Education and Information Communication Technology in addition to their electives. Group C, D and E have a total enrolment of 87, 91 and 84 respectively. The total sample size is four hundred and thirty-six (435). The sampling technique used is purposive sampling because the researchers teach all these students' groups in the college.

\subsection{Instrument}

The main instrument was test constructed by qualified Course Lecturers from the forty-six colleges of Education and moderated by the Course Coordinators (Senior Lecturers) from University of Cape Coast, UCC. The test was administered within six weeks interval between the 4 th and $10^{\text {th }}$ week of the 2018/19 academic year. The test items were made up 20 objectives questions with four distractors. It was constructed not to only to test for knowledge and understanding but also application of knowledge.

\subsection{Validity and the reliability of the instrument}

The test items were constructed by selected qualified Course Lecturers from the forty six CoE across the country and were moderated by Course Coordinators from University of Cape Coast to ensure its face and content validity of the instrument. The instrument was moderated by Senior Lecturers at UCC and also administered under strict supervision in all the forty-six (46) Colleges of Education in Ghana. The instrument was found to be reliable with a reliability coefficient of 0.7 .

\subsection{Data collection procedure}

Data was collected after the first and second supervised quizzes were written and marked by Course Lecturers with a general marking scheme provided by UCC.

\subsection{Data analysis}

The data were analysed using both descriptive statistics and inferential statistics. The descriptive statistics was used to find the average means, the range and the standard deviations of the two quizzes whiles the inferential statistics was used to find the t-test results of both quiz 1 and quiz 2 .

\section{Results and discussion}

\subsection{Introduction}

This chapter discusses the findings of the study in relation to the research questions and the null hypothesis. However, from the attendance sheet of both quizzes, students had the same number of attendance and this is the demography of the First year first batch of four year Bachelor Degree of Education students in Abetifi Presbyterian College of Education, Abetifi Kwahu in Ghana. 
Table 1. Demography of first batch of B.ED students

\begin{tabular}{ccc}
\hline Groups & Frequency & Percentage \\
\hline GROUP A & 86 & 19.8 \\
GROUP B & 87 & 20.0 \\
GROUP C & 87 & 20.0 \\
GROUP D & 91 & 20.9 \\
GROUP E & 84 & 19.3 \\
Total & $\mathbf{4 3 5}$ & $\mathbf{1 0 0 . 0}$ \\
\hline
\end{tabular}

From Table 1, it is clearly seen that Group D had the largest enrolment and Group E had the least enrolment. Group D had the highest enrolment because studies has shown that there a drive for Mathematics and Information and Communication Technology (ICT) Education ${ }^{[6]}$.

\subsection{Research question one}

What is the performance level of student teachers in both General Biology quiz one and quiz two?

The research question sought to find out the performance level of student teachers' performance in both quizzes organised by UCC.

Table 2. Average scores of students in both quiz one and quiz two

\begin{tabular}{|c|c|c|c|}
\hline & & QUIZ 1 & QUIZ 2 \\
\hline \multirow{3}{*}{ GROUP A } & Mean & 11.72 & 10.91 \\
\hline & $\mathrm{N}$ & 86 & 86 \\
\hline & Std. Deviation & 3.20 & 2.80 \\
\hline \multirow{3}{*}{ GROUP B } & Mean & 11.77 & 11.89 \\
\hline & $\mathrm{N}$ & 87 & 87 \\
\hline & Std. Deviation & 3.70 & 2.24 \\
\hline \multirow{3}{*}{ GROUP C } & Mean & 10.25 & 10.71 \\
\hline & $\mathrm{N}$ & 88 & 88 \\
\hline & Std. Deviation & 3.23 & 2.54 \\
\hline \multirow{3}{*}{ GROUP D } & Mean & 12.38 & 11.86 \\
\hline & $\mathrm{N}$ & 91 & 91 \\
\hline & Std. Deviation & 3.84 & 2.29 \\
\hline \multirow{3}{*}{ GROUP E } & Mean & 12.01 & 12.25 \\
\hline & $\mathrm{N}$ & 84 & 84 \\
\hline & Std. Deviation & 3.87 & 1.96 \\
\hline \multirow{3}{*}{ Total } & Mean & 11.63 & 11.52 \\
\hline & $\mathrm{N}$ & 435 & 435 \\
\hline & Std. Deviation & 3.64 & 2.45 \\
\hline
\end{tabular}

The average score of 11.63 and 11.52 were recorded for both quiz one and quiz two respectively. This indicates that the student teachers performed slightly higher in quiz one than in quiz two with an average score of 10.00 in both quizzes. The difference in the overall average mean of both quizzes is about $0.95 \%$. This could also mean that the students 
approached both quizzes with the same all serious since it was the first of its kind in Ghana. Again, the students might have approached it with all the attention and urgency it deserves because it their first supervised test under the supervision of UCC in General Biology. However, in terms of differences in standard deviation of both quizzes, the deviation was wider in quiz 1 than in quiz 2. It could be could be seen that most of the students obtained a higher score in quiz 1 hence a deviation of 3.64. In quiz 2, a standard deviation of 2.44 was recorded. This might also explained why no student had an outstanding performance. The difference in standard deviation in quiz 1 was almost $33 \%$ from quiz 1 .

\subsection{Hypothesis testing}

$\mathrm{H}_{01}$ : There is no significant mean difference between the mean score of students in General Biology in quiz 1 and quiz 2.

In order the answer the null hypothesis $\left(\mathrm{H}_{01}\right)$ stated above, the scores of the students quiz one and two were analysed using Paired Sample Test. The result as indicated in Table 3 below revealed that there was significant difference between the scores obtained in quiz one and quiz two $(\mathrm{P}=0.519, \mathrm{p}>0.05 \mathrm{df}=434)$, hence we fail to accept the null hypothesis and accept the alternative hypothesis. The quiz one recorded a mean score of 11.63 as compared to quiz two which recorded a mean of 11.52 .

Table 3. Paired Sample Test with Equal Variances between the two quizzes summary

\begin{tabular}{ccccccc}
\hline & Mean & Std. Deviation & Std. Error Mean & t & df & $\begin{array}{c}\text { Sig. } \\
\text { (2-tailed) }\end{array}$ \\
\hline QUIZ1 - QUIZ2 & 0.11034 & 3.56917 & 0.17113 & 0.645 & 434 & 0.519 \\
\hline
\end{tabular}

\section{Conclusions and recommendations}

The new Sustainable Development Goal (SDGs), goal 4, states to ensure inclusive and equitable quality education and promote lifelong learning opportunities for all ${ }^{[8]}$. This can only be achieved if we invest in recruiting, supporting and empowering teachers and enabling good quality teaching to dominate the classroom.

Students' teachers in Abetifi College performed better in their first supervised quiz in General Biology than in the second quiz.

Again, a mode 14 was recorded in quiz 2 as against 11 in quiz 1 with a range of 20 and 18 respectively. This could be explained that student teachers approach the first quiz with all the seriousness it deserves but relaxed a little for the second quiz. This can be seen from thee standard deviations of 3.64 in quiz 1 to 2.45 in quiz 2. It also revealed that assessment tools should be varied to keep student teachers on the alert to write or answer questions in different format such as presentations, project work and practicum.

Statically, there was significant difference between the two quizzes that were written $(p=0.519, p<0.05, d f=434)$. This could also suggest that the Course Lecturer did not put in the same effort during the preparation for quiz 1 and quiz 2. General Biology is a course which should be taught with the observation of the natural environment and efficient Laboratory. It could also be seen that the students adopted a different attitude for the two quizzes.

\subsection{Recommendations}

Based on the findings of the study, it is recommended that

1) Ministry of Education, National Council for Curriculum and Assessment, University of Cape Coast, University of Education, Winneba and other affiliate institutions should make some structural changes in the discipline of science education in Colleges of Educations that will encourage the use of practical skills in the teaching, learning and assessment of General Biology.

2) The National Teaching Council (NTC), the University of Cape Coast, University of Education, Winneba and other affiliate institutions should regularly and periodically team up with Colleges of Education and organize seminars and presentations for Science Course Lecturers on some pedagogical skills.

3) This study also indicates the need for further research in the following areas:

a. Effective use of time during the teaching of General Biology in the Colleges of Educations in Ghana.

b. the perception of Course Lecturers about the New Four Year Bachelor of Education Degree Programme;

c. The design of professional learning programs to support Course Lecturers' understanding of how to maximize learning opportunities.

\subsection{Suggestion for the further studies}

Based on this study, the following suggestions are made:

1) The study can be carried in different science courses to investigate the readiness of the student teachers to the new 
four year degree programme.

2) The sample size of the study was small; it should be replicated with a large sample size and conducted in to different schools to provide a generalization of its effect for pedagogy development.

\section{References}

[1] Anamuah-Mensah, J., Mereku, D. K., \& Ampiah, J. G. TIMSS 2007 Ghana Report: Findings from IEA's trends in international mathematics and science study at the eighth grade. Accra: Adwinsa Publications (Gh) Ltd.; 2009.

[2] Anamuah-Mensah, J. Teacher education and practice in Ghana. In R. Kolawole, \& P. Kupari, Educatonal issues for sustainable development in Africa. Lasonen Johana: Institute for Educational Research; 2006. p.28-40.

[3] Bawa, M. The effect of multimodal instructional approaches on college of education students' understanding of chemical bonding. University of Education, Winneba: Unpublished dissertation. 2014.

[4] Colleges of Education Weekly Journal News. Release of first semester exams results: Colleges record abysmal perfomance of level 100 students on the new B. ED. 2019. p. 1.

[5] Hake, R. interactive- engagement verus traditional methods: A six-thousand-student survey of mechanic test data for introductory physics courses. America Journal of Physics. 1998; 66: 64-74.

[6] National Council for Curriculum and Assessment. National Pre-tertiary Education Curriculum Framework for developing subject curricula. Accra: MOE. 2018.

[7] NCTE. Colleges of Education: The journey so far. Accra: T-TEL. 2015.

[8] United Nations. Transforming our world:The 2030 Agenda for Sustainable Development. New York: United Nations. 2015. 